IZA DP No. 881

Worker-J ob Matches, J ob Mbbility, and Real Wage Cyclicality

Robert A. Hart

October 2003 


\title{
Worker-Job Matches, Job Mobility, and Real Wage Cyclicality
}

\author{
Robert A. Hart \\ University of Stirling \\ and IZA Bonn
}

\section{Discussion Paper No. 881 \\ October 2003}

\author{
IZA \\ P.O. Box 7240 \\ D-53072 Bonn \\ Germany \\ Tel.: +49-228-3894-0 \\ Fax: +49-228-3894-210 \\ Email: iza@iza.org
}

This Discussion Paper is issued within the framework of IZA's research area Mobility and Flexibility of Labor. Any opinions expressed here are those of the author(s) and not those of the institute. Research disseminated by IZA may include views on policy, but the institute itself takes no institutional policy positions.

The Institute for the Study of Labor (IZA) in Bonn is a local and virtual international research center and a place of communication between science, politics and business. IZA is an independent, nonprofit limited liability company (Gesellschaft mit beschränkter Haftung) supported by Deutsche Post World Net. The center is associated with the University of Bonn and offers a stimulating research environment through its research networks, research support, and visitors and doctoral programs. IZA engages in (i) original and internationally competitive research in all fields of labor economics, (ii) development of policy concepts, and (iii) dissemination of research results and concepts to the interested public. The current research program deals with (1) mobility and flexibility of labor, (2) internationalization of labor markets, (3) welfare state and labor market, (4) labor markets in transition countries, (5) the future of labor, (6) evaluation of labor market policies and projects and (7) general labor economics.

IZA Discussion Papers often represent preliminary work and are circulated to encourage discussion. Citation of such a paper should account for its provisional character. A revised version may be available on the IZA website (www.iza.org) or directly from the author. 
IZA Discussion Paper No. 881

October 2003

\title{
ABSTRACT \\ Worker-Job Matches, Job Mobility, and Real Wage Cyclicality*
}

Using the British New Earnings Survey Panel Data from 1980 to 2001, this paper examines male and female real wage cyclicality. Estimation is undertaken separately for job stayers and job movers. A unique data advantage compared to earlier studies is that movers are defined by job changes both within and between companies. Core estimates concern real hourly standard wage rates. Special features include (a) differentiating between white- and blue-collar workers, (b) delineating job stayers by length of job tenure, (c) examining the cyclicality of the average overtime premium, (d) distinguishing between hourly wage earnings and hourly wage rates. Wage cyclicality in Britain is found to be significantly greater than comparable United States estimates.

JEL Classification: E32, J31, J62

Keywords: $\quad$ real wage cyclicality, job stayers, job movers

\author{
Robert A. Hart \\ Department of Economics \\ University of Stirling \\ Stirling FK9 4LA \\ Scotland \\ Email: r.a.hart@stir.ac.uk
}

\footnotetext{
* This project was funded by the Nuffield Foundation's Social Science Small Grants Scheme. I am very grateful to Paul Devereux and Olaf Hübler for very useful comments on an earlier draft of the study and to Elizabeth Roberts for excellent research assistance. All remaining errors and misconceptions are my own.
} 


\section{Introduction}

Up to the early 1990s, most empirical studies of wage behaviour concluded that, at best, real wages are weakly pro-cyclical. This view was based largely on the findings of industry- or nationallevel studies. In recent times, several articles have made the central claim that the observed lack of cyclical wage responsiveness is largely a measurement problem (for example, Bils, 1985 and Solon, Barsky and Parker, 1994). They show that using longitudinal microdata serves to alter earlier notions. In particular, United States wages have been found to be significantly procyclical. Typically, for those individuals remaining in the same job, it has been found that a one-point increase in the rate of unemployment is associated with a $1 \%$ decrease in the wage. One reason for the discrepancy between macro and micro approaches is that the latter allow researchers to remove major compositional biases that are inherent in aggregate data. More recent micro work suggests that strong wage cyclicality is not a universal phenomenon, however. Devereux (2001) finds that the degr ee of U.S. wage procyclicality varies considerably across different types of worker and payment methods. For example, in contrast to hourly-paid workers, the earnings of salaried workers display quite weak cyclicality.

This paper investigates the wage cyclicality of British individual males and females using one of Europe's best sources of longitudinal microdata, the British New Earnings Survey Panel Data (NESPD). The period of analysis is from 1980 to 2001. The NESPD is based on establishment-level payroll records and one of its advantages is that response bias is much less likely compared to employee-based surveys.

These data offer an especially interesting element of value added in relation to earlier studies. Researchers have typically distinguishe $\mathrm{d}$ between job stayers and job movers. 
It is argued that, a priori, we would expect the degree of procyclical response of movers to exceed that of stayers. The NESPD allow us to define these two groups with far greater precision. Workplace job matches refer to single jobs within the company rather than the broader definition of employer-employee matches.

Therefore, a job stayer within the NESPD literally refers to an individual who remains within a single job in a given company. A job mover is an individual changing jobs either within a given company or between companies. This distinction is important because many job changes are internal to the company (e.g. Rosenbaum, 1979 and 1984). I present two pieces of supporting evidence that serve to reinforce the advantages of identifying job changes inside the company. First, about $50 \%$ of all job moves are internal within companies. Second, the real wage changes of withincompany job movers are of similar magnitudes to those associated with between company moves.

The need to distinguish between wage movements of job stayers and job movers is often related to the concepts of specific human capital and rent sharing (see Section 2). Essentially, this study emphasises job specific human capital while earlier micro work on worker-employer matches has concentrated on company specific human capital. In both cases, and following standard Mincer-type arguments, it is important to capture the roles of individual work experience and job tenure. The experience variable can be constructed using the NESPD by following cohorts of individuals from when they first entered the panel. This means that the ages of the individuals used in this study are relatively young, within the range of 17 to 43 years over the entire period of analysis. As discussed later, the interpretation of the wage unemployment findings needs to take account of this age distribution. However, without serious loss of precision, estimates for job stayers of all ages are also 
provided. British real hourly wages - for both job stayers and job movers - are found to be highly pro-cyclical. In fact, the evidence strongly supports the conclusion that wage cyclicality is considerably more pronounced than in the United States, an economy noted for its relatively flexible labour market.

Three additional aspects of the analysis are as follows. First, I explore the relative wage cyclicality between short- and long-duration job stays. Second, in line with Devereux's work, I investigate wage cyclicality between predominantly salaried and predominantly hourly-paid workers. Third, the NESPD allows us to demarcate - with far more precision than any comparable data set - between standard and premium overtime wage payments. The contribution of overtime working is potentially important to the study of wage cyclicality. Earlier work has attempted to capture its effect by differentiating between the standard wage and wage earnings which are, respectively, exclusive and inclusive of overtime payments. With present data it is possible to separate standard pay for both non-overtime and overtime workers as well as to calculate the average overtime premium for individuals in the latter group. This permits more detailed comparative performance of pay for these two types of worker.

\section{Stayers, movers, and wage cyclicality}

Why is it preferable to distinguish between job stayers and job movers in the analysis of wage cyclicality? There are no hard and fast a priori reasons to expect significantly different wage responsiveness between these two groups. But there are lines of thought that suggest that procyclical wages may be relatively less pronounced among job stayers. 
One idea links stayers to the accumulation of job-specific investment or matchspecific capital. "Maintenance of existing employment attachments creates shared rents which introduce a wedge between the value of the current job and outside opportunities. Rents relax momentarily arbitrage constraints between current wages, current fortunes of the company, and general labor market conditions...." (Rosen, 1985). In particular, positive rents may serve to blunt the degree of association between current wages and productivity shocks since bargaining parties are keen to avoid costly separations (Hashimoto, 1979).

Extending this line of argument, there is reason to investigate whether the wage cyclicality of long-term job stayers differs from that of short-term stayers. First, consider match-specific capital. Companies may invest particularly heavily in search and hiring in order to match the most suitable individual to their highest value -added jobs. To the extent that such job matches have the longest expected duration, and are reinforced by the company protecting investments through rent sharing, we might expect lower wage cyclicality to be attached to long-term job stayers. Note that, since an important element of match-specific capital is invested prior to the commencement of a job, we would expect the effects of rent sharing to apply to each and every year of the job's duration. Second, suppose that investment specificity derives principally from on the job training coupled, perhaps, with team-based interactive skills. In this event, rents may be acquired cumulatively as workers gain in tenure - based experience. In this instance, long stay workers may well be more protected against wage fluctuations than short-stay because of rent accumulation. But this would not reveal itself until some time into job tenure in which case the wage effects of long job stays would not be observed until an initial period has elapsed. 
An interesting conceptual issue arises when delineating between worker-job matches and worker-company matches. Suppose that rent sharing due to specific skill acquisition is the prime reason for low stayer wage cyclicality. A critical question concerns the relative degree to which rents derive from job specific as opposed to company specific knowledge acquisition. For example, the latter may stem from the acquisition of organisational capital (A oki, 1984). If rents derive primarily from job specific skills then it is important to separate worker-job matches both within and between companies. This is what is captured in the current paper. In this event, using worker-employer matches may serve to overestimate wage cyclicality of job stayers. It would fail to remove the enhanced wage cyclicality of internal job movers. If, on the other hand, company specific human capital is the predominant type of investment then defining job moves on the basis of intra- and inter-company moves would serve to overestimate wage cyclicality of movers. Here, the wage cyclicality of both job stayers and job movers within the company would be reduced due to rent sharing on a company-level basis.

By contrast, where job moves occur, current wages of movers may be more reflective of short-run changes in (average) marginal product. This is likely to be particularly true of relatively productive workers. During the expansion phases of the cycle, such workers may find it in their interest to initiate job search in order to find higher wages associated with increased job opportunities. During downturns, enforced job separations may require that individuals have to accept downward wage adjustments in order to achieve job offers. In measuring the degree of wage cyclicality associated with job moves, there is a clear advantage in the fact that the NESPD records all job moves - i.e. whether occurring within or between companies. For many workers, potential job mobility embraces search for higher paid jobs within the 
same company. Advantages include the avoidance of mobility and other transaction costs as well as enhancing the probability of future internal promotion. Since internal jobs opportunities may entail competition with external job applicants then, for many individuals, the hiring process may differ little from attempting to find a better job in an outside company.

Some job moves are likely to involve weak or acyclical wage associations, however. Four examples are as follows. First, changes in geographical location may be undertaken with a view to maximising more broadly based psychic rather than jobrelated income. Second, individuals may quit because of dissatisfaction with their current job rather than for the primary purpose of finding a better-paid job. For example, Bartel and Borjas (1981) find that many U.S. older workers quit work for this reason and that such quits do not result in significant wage increases. Third, consider a standard supply-side story. Let the company's wage rate rise due to an upward shift in product demand. Suppose that leisure is a normal good and there are no alternative in-house jobs or opportunities to vary per-period hours of work. The income effect of the wage increase may then manifest itself in the form of some workers seeking less demanding jobs elsewhere at their former real wage levels. Fourth, where job changes within a household involve more than one individual - for instance, partners or adults with cohabiting older children - it may not be possible for all parties to attain simultaneously their optimal search outcomes.

\section{Non-overtime and overtime workers}

Why is it potentially important to distinguish between non-overtime and overtime workers in the analysis of wage cyclicality? The principal reason is that wage cyclicality of overtime workers is determined by the relative responsiveness of both 
the standard and premium components of hourly pay. Combining hourly standard and premium pay produces hourly earnings. Earnings cyclicality of an overtime worker derives from fluctuations in (a) the standard wage, (b) premium rates of pay for overtime hours and (b) the proportion of overtime to total hours. The NESPD allows us to obtain insights into the contributory roles played by these components.

Three broad sets of overtime-related questions are tackled in the subsequent empirics. First, does the cyclicality of the standard pay of an overtime worker differ from a nonovertime counterpart? If overtime hours are highly procyclical then overtime workers may be protected, in part, against excessive fluctuations in real wage income by being offered relatively stable real standard hourly rates. Second, is the average premium rate for overtime hours itself procyclical? At the simplest level, the overtime premium may be represented as a constant mark-up (for example, time-and-a-half) of the standard hourly wage rate. In reality, it is quite common for companies to offer higher premia as weekly overtime hours increase. For example, higher marginal rates may apply to weekend compared to weekday overtime. So the marginal and the average premium may entail procyclical pay effects as increased hours' demand necessitates longer workweeks. ${ }^{1}$ Third, over and above standard pa y and overtime premia, does the proportion of overtime to total weekly hours cause greater real

\footnotetext{
${ }^{1}$ Santamäki (1983) was the first to introduce the notion that the overtime premium itself might be an increasing function of overtime hours. This work referred to company-level pay. Hart and Ruffell (1993) undertook associated empirical work. At the individual level, it is a common British practice for overtime workers to face a schedule of premium overtime rates applying to different parts of the workweek (Incomes Data Services, 1997). The lowest rate might apply to overtime that extends the standard working day with higher rates paid for weekend work. It follows that if average weekly hours vary procyclically then the average premium of individuals with multiple overtime rates would also be expected to be procyclical even if marginal overtime rates remain constant.
} 
hourly earnings cyclicality? Even if standard pay and the average overtime premium were acyclical, hourly earnings could still display strong procyclicality if the proportion of overtime to total hours varied directly to the business cycle and if overtime were compensated at a premium in excess of basic rates.

\section{Within- and between- company job changes}

The importance of observing both within - and between company job changes is underlined by the information presented in Table 1. These NESPD data are only available for the years 1996 and 1997. Of all full time male and female job changes between these two years, roughly half occurred within the same company and half involved changing company. As for real wage changes between these two years, both genders remaining in the same job averaged a 5.8 percent increase. Changing jobs both within and between companies involved substantially larger wage changes - between 11 and 16 percent. Within-company job changes involved slightly higher average wage increases. $^{2}$ Of course, we cannot infer relative wage cyclicality from these findings. But they do indicate that wage changes within single jobs may differ significantly from changes between jobs whether or not the latter are within the same company.

On this evidence, there is less support for dichotomising between worker-employer matches compared to worker-job matches. The former involves separating withincompany wage changes (on the job or between jobs) on the one hand and betweencompany wage changes on the other. We should note, however, that all these mean

\footnotetext{
${ }^{2}$ As pointed out to me by Olaf Hübler, the reason for the relatively high wage increases associated with job changes within the company is that an internal job change may well be more likely to be associated with a promotion than a betweencompany job change. Unfortunately, the available data do not allow us to investigate internal or external promotions.
} 
estimates of wage changes - and particularly those involving job moves - belong to wide distributions, as indicated by their standard deviations. Some individuals experienced very significant wage reductions and others enjoyed very large increases.

Overall, the latter dominated the former since all distributions are positively skewed.

Table 1 Percentages of full-time male and female job changes and real hourly standard wage changes within and between companies, 1996/7 (NESPD)

\begin{tabular}{l|c|c|}
\hline & \multicolumn{2}{|c|}{ Percentage of total job changes } \\
\hline Change of company & 54 & Females \\
Within same & 46 & 51 \\
company & & 49 \\
\hline & Average perce ntage change in real hourly standard \\
& \multicolumn{2}{|c|}{ wage } \\
\hline Within same job & $(18.7)$ & 5.8 \\
Job change within & 13.7 & $(16.1)$ \\
company & $(24.0)$ & 15.7 \\
\hline $\begin{array}{l}\text { Job change between } \\
\text { companies }\end{array}$ & 11.4 & $124.2)$ \\
\hline
\end{tabular}

Notes: Figures in brackets are standard deviations. The percentages are based on 36679 males (18920 females) who remained in the same job, 1920 males (1360 females) who changed job within the same company, and 1973 males (1144 females) who changed companies. 


\section{Estimation and panel structure}

The specifications that follow distinguish among the real standard hourly wage rate, the average overtime premium and real average hourly earnings. To illustrate the basic methodology, I concentrate on the first of these variables.

I adopt the estimation strategy developed by Solon, Barsky and Parker (1994) (see also Devereux, 2001). These authors start with a statistical model in which the wage is expressed in terms of the business cycle, as proxied by the cyclical behaviour of unemployment. Specifically, the real wage is expressed as a function of a quadratic time trend, the deviation of the unemployment rate from its own quadratic trend, individual fixed effects, a cubic in worker's years of work experience and the interaction of experience and fixed effects. I also add a cubic in tenure in the current job. First differencing removes the influence of individual (and company) heterogeneity.

For individual $\mathrm{i}$ in job $\mathrm{j}$ at time $\mathrm{t}$, the differenced within-job estimating equation (i.e. job stayers) is given by

(1) $\Delta \ln w_{i j t}=\alpha_{0}+\alpha_{1} X_{i j t}+\alpha_{2} T_{i j t}+\alpha_{3} \Delta U_{t}+\alpha_{4}$ Year $_{t}+v_{t}+\varepsilon_{i j t}$. where $w_{i j t}$ the real standard hourly wage rate, $X_{i j t}\left(T_{i j t}\right)$ is a cubic in labour market experience (job tenure), $U_{t}$ is the national unemployment rate, $v_{t}$ is a year specific error and $\varepsilon_{i j t}$ is a random error term. ${ }^{3}$ A two-step estimation method gets round the problem of using national-level unemployment rates; the associated year-specific

\footnotetext{
${ }^{3}$ In unreported regressions, I experimented with additional controls added to equation (1). These included industries, regions, whether or not individuals were covered by a collective agreement. These had virtually no effect on the wage-unemployment estimates compared to the above specification.
} 
error is likely to result in OLS underestimating the standard errors (Moulton, 1986). Letting $D_{t}$ denote a dummy variable equal to 1 if the observation is from year $t$, in stage 1 we estimate

(2) $\Delta \ln w_{i j t}=\beta_{0}+\beta_{2} X_{i j t}+\beta_{3} T_{i j t}+\sum_{t=1}^{T} \phi_{t} D_{t}+\varepsilon_{i t}$.

In stage 2 the estimates of the year dummies, $\hat{\phi}_{t}$, are regressed on the change in unemployment and the time trend, or

(3) $\hat{\phi_{t}}=\delta_{0}+\delta_{2} \Delta U_{t}+\delta_{2} Y e a r_{t}+v_{t}$.

This second stage regression is weighted to reflect the number of individuals observed in a given year.

Card (1995) suggests a simple test of the specification in (2). Suppose that $\alpha_{2} \Delta U_{t}$ is decomposed into $\gamma_{1} U_{t}+\gamma_{2} U_{t-1}$ and the estimation process carried out as before. If $\gamma_{1}$ is found to be significant and $\gamma_{2}$ insignificant then this suggests that a Phillips curve specification should be preferred. Alternatively, if estimates of $\gamma_{1}$ and $\gamma_{2}$ are found to be of equal magnitude and opposite signs then this lends support to the present choice of model.

I now consider wage changes of job movers. Here, the estimating equation is given by

(4) $\ln w_{0 i j t}-\ln w_{l i k t}=\phi_{0}+\phi_{1} X_{i j t}+\phi_{2} \Delta U_{t}+\phi_{3} Y e a r_{t}+\eta_{t}+\mu_{i j t}$. 
The wage change consists of the log difference of the starting wage $w_{0}$ of individual i in job $j$ (with $T_{i j t}=0$ ) and the last wage $w_{l}$ of individual $\mathrm{i}$ in job $k$, with $k=j-1$. $\eta_{t}$ is a year specific error and $\mu_{i j t}$ is a random error term. Equation (4) is estimated via the two-stage procedure outlined in equations (2) and (3) for job stayers.

In all regressions, the change in the log wage is multiplied by 100 . The estimated coefficient on the change in unemployment then reflects the percentage change in the wage for a one-point increase in the unemployment rate.

As discussed in the previous section, overtime workers additionally receive a premium component of the wage. Calculating average hourly real earnings, $e$, simply involves averaging pay over standard and overtime components of these workers while $e=w$ for non-overtime workers. So, in measuring the influence of overtime working on wage cyclicality, e can simply replace $\mathrm{w}$ in the foregoing regression equations.

But, the NESPD permits a more detailed investigation of the role of premium pay for overtime hours. In particular, it is possible to estimate an individual's average overtime premium, $p_{i}$. This is given by

(5) $p_{i j t}=\frac{\left(e_{i j t} / w_{i j t}\right) h_{i j t}-h_{i j t}^{s}}{v_{i j t}}$ where $h$ is total weekly hours, $h^{s}$ is standard weekly hours, and $v=h-\mathrm{h}^{\mathrm{s}}$.

Data are taken from the NESPD for the years 1980 to 2001. A job change is coded whether or not it takes effect between companies or within the existing company. ${ }^{4} \mathrm{I}$

${ }^{4}$ The NESPD questionnaire requires employers to indicate whether an employee has worked in the same job within the organisation for one year or more. If the employee has changed to a different job or been promoted within the past 12 months then the 
concentrate on full time males and females. There are no double jobholders. Since the NESPD is based on employers' payrolls, education and schooling information is not available. Accordingly, measures of the length of work experience have to be obtained by unconventional means. To this end, the data set is confined to thirteen cohorts of individuals born each year from 1958 to 1970 . Members of each cohort were then observed - from 1975 onwards - entering the NESPD in seven age groups; these were the ages of 17, 18, 19, 20,21, 22 and 23 and above. Those entering at the youngest age would have received the minimum level of compulsory education in Britain while successive ly older age groups would typically coincide with higher levels of pre-work education and training. ${ }^{5}$ Experience at any given time period is simply the count of years from the year of entry into the panel. Job tenure is the count of years since the last indicated job change. ${ }^{6}$

The above selection criterion produced 4861 males and 4489 females observed in job 1 . A proportion of these are then observed in job 2 and then successive proportions on to jobs 3, 4 and so on. The numbers observed in each job are shown in Table 2. Average job tenure is shown in column 2. Column 3 records the average age of individuals at each job change. The last column of Table 2 shows the average percentage real

employer is required to submit 'under one year'. In general, the data do not identify whether or not a given job change within the past year took place within the company or resulted from a new hire. We can obtain information for the year 1996/7, however. (See Table 1 and associated discussion.)

${ }^{5}$ Unfortunately, it is not possible to ascertain whether a spell of unemployment was experienced prior to first entering the NESPD sample.

${ }^{6}$ The data set includes only those individuals from the selected cohorts with complete NESPD histories. Therefore, after entering the panel they are followed through to 2001 or to the year at which they disappear from the panel and do not re-enter. 
standard wage change declines from 23 percent between jobs 1 and 2 to an average of 1.7 percent between jobs 8 and 9. The female decline is very similar, ranging from an

Table 2 Observed frequency of workers by job number, average tenure in each job, average age at job change, and average wage change at job change: 1980-2001

\begin{tabular}{|c|c|c|c|c|}
\hline Job & $\begin{array}{c}\text { Number of } \\
\text { individuals } \\
\text { observed }\end{array}$ & $\begin{array}{c}\text { Average tenure } \\
\text { (years) }\end{array}$ & $\begin{array}{l}\text { Average age at } \\
\text { job change }\end{array}$ & $\begin{array}{c}\text { Percentage change } \\
\text { in real standard } \\
\text { wages between } \\
\text { jobs }\end{array}$ \\
\hline $\begin{array}{l}\text { MALES } \\
1\end{array}$ & 4861 & 2.7 & $(21.5)^{b}$ & - \\
\hline 2 & 1480 & 4.1 & 25.7 & 23.0 \\
\hline 3 & 766 & 3.8 & 28.3 & 14.0 \\
\hline 4 & 445 & 3.6 & 30.2 & 13.6 \\
\hline 5 & 281 & 3.2 & 31.8 & 8.3 \\
\hline 6 & 181 & 2.8 & 32.6 & 10.5 \\
\hline 7 & 117 & 2.9 & 34.3 & 7.7 \\
\hline 8 & 68 & 2.4 & 34.9 & 5.3 \\
\hline 9 & 49 & 2.7 & 36.6 & 1.7 \\
\hline $\begin{array}{l}10 \text { and } \\
\text { above }\end{array}$ & 58 & $3.2^{\mathrm{a}}$ & - & - \\
\hline \multicolumn{5}{|l|}{ FEMALES } \\
\hline 1 & 4489 & 2.3 & $(20.7)^{b}$ & . \\
\hline 2 & 1308 & 3.4 & 24.0 & 19.7 \\
\hline 3 & 658 & 3.6 & 26.9 & 11.8 \\
\hline 4 & 353 & 3.4 & 29.3 & 9.8 \\
\hline 5 & 183 & 3.3 & 31.0 & 8.9 \\
\hline 6 & 95 & 2.7 & 31.7 & 4.4 \\
\hline 7 & 56 & 2.5 & 32.6 & 5.2 \\
\hline 8 & 30 & 2.1 & 33.2 & 5.8 \\
\hline 9 & 15 & 2.0 & 35.3 & -0.9 \\
\hline $\begin{array}{l}10 \text { and } \\
\text { above }\end{array}$ & 20 & $3.5^{\mathrm{a}}$ & - & - \\
\hline
\end{tabular}

Notes: ${ }^{a}$ denotes weighted mean; ${ }^{b}$ denotes average age when entered panel.

average of 19.7 percent between jobs 1 and 2 to an average of -0.9 percent between jobs 8 and 9. Topel and Ward (1992) argue that relatively rapid wage growth among young U.S. males who change jobs arises from improving job matches through on-the-job search. For this type of reason, we might expect wage increases associated with job moves to decline with age (Bartel and Borjas, 1981; Mincer, 1986). This is certainly 
the case for the present cohorts, as shown in Figure 1. This shows real wage changes of male and female job movers at given ages. Both groups achieve wage increases in excess of 15 percent associated with job moves in their late teens/early twenties. These reduce to changes of between 5 to 15 percent by their mid-twenties to mid-thirties and then somewhat lower, but more erratic, up to the age of 40 .

The observed sample describes a relatively young cohort of males and females, ranging from 17 to 43 years over the entire period. Job changes occur most frequently in the first years of work experience. Male workers average 1.8 job changes (females, 1.9 changes) after 5 years and only 25 (2.7) after 10 years. By the end of 20 years both males and females average 4 job changes and so there is only a modest increased average of job changes between years 5 and 20 compared to the first 5 years. Moreover, early job changes are associated with relatively high percentage wage increases compared to later job changes.

Figure 1 Average percentage wage increases for job changes at ages 19 to 40

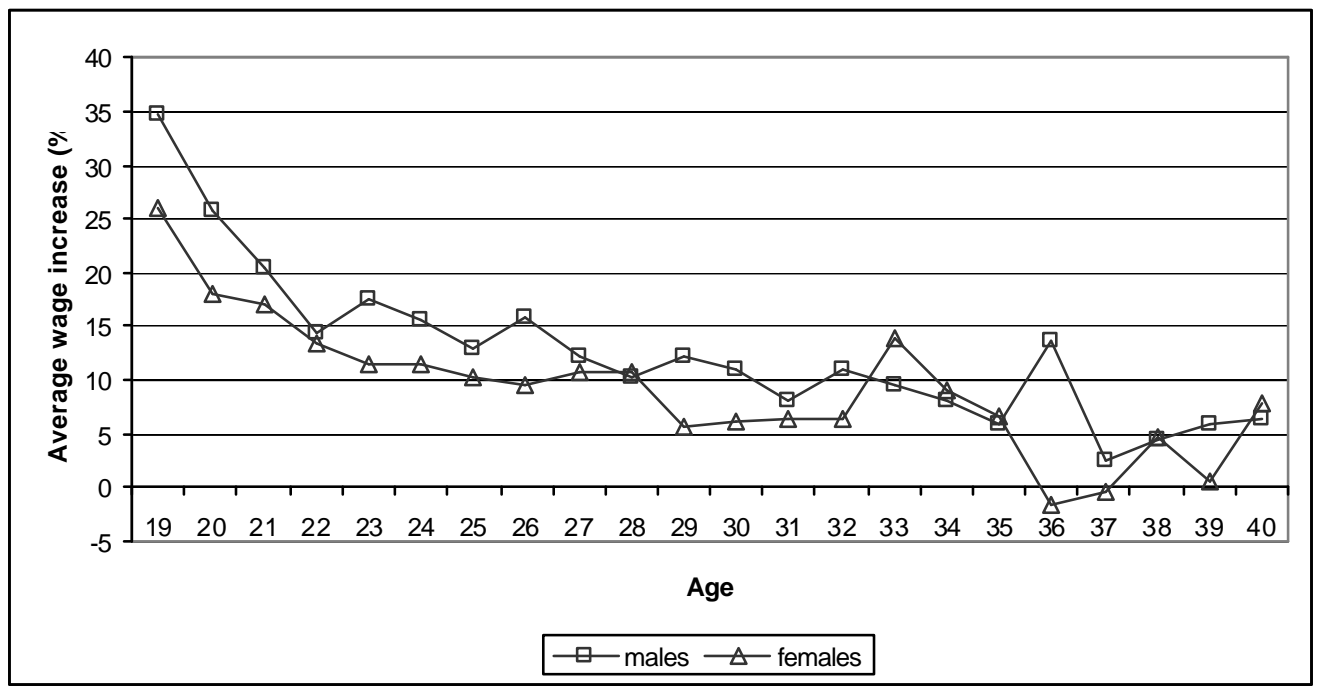


Wage increases associated with job changes decline with age. This may mean that job movers' wage cyclicality in our relatively young sample overestimates that of the population as a whole. ${ }^{7}$ An upturn in the cycle will be especially favourable to young workers since it improves their ability to achieve significantly better job matches. Downturns may also have more adverse impacts on young persons' wages. For example, companies that downsize their workforces may practice a last-in-first-out policy and this is likely to impact disproportionately on the young. Associated job search in a declining market may result in relatively adverse wage changes. As for job stayers, our sample may also overestimate the degree of wage cyclicality. Consider, as in Section 2, that the degree of wage cyclicality of job stayers is negatively associated with human capital investment and rent sharing. Ceteris paribus, higher investments are likely to be expended on workers for whom strong job matches have already been achieved. This is more likely to occur within later jobs, when sufficient job sampling trial and error has taken place.

As noted earlier, evidence is also presented (in Section 7) for all age groups of job stayers. It is fairly safe to conclude from these findings, that our core results are representative of this wider sample.

\section{Results}

Table 3 shows second-stage estimates (e.g. equation (3)) - separated into job stayers and job movers - for the complete male/female samples using real standard hourly wages. For male job stayers, the estimated coefficient on the change in une mployment variable is -1.2 : a one point fall in the rate of unemployment is

\footnotetext{
${ }^{7}$ The relative youthfulness of the sample is further increased by the fact that some individuals are observed in the early years and then dropped out of the NESPD.
} 
associated with a 1.2 percent increase in the standard wage rate. The equivalent estimate for male job movers is -2.0 , indicating a rise in the standard wage of 2 percent for a one-point fall in the rate of unemployment. The respective female estimates are -1.30 and -1.73 . Both males and females exhibit very strong real wage procyclicality whether remaining in the same job or changing jobs. Moreover, the wage responsiveness of job movers is greater than for job stayers. Separating the change in unemployment into current and lagged rates produces reasonably strong support for the adopted wage curve specification.

Table 3 Effect of a change in rate of unemployment on log of real standard hourly wage rates, NESPD 1980 - 2001.

\begin{tabular}{|c|c|c|}
\hline MALES & $\begin{array}{c}\text { Job Stayers } \\
\text { (N: 16940) }\end{array}$ & $\begin{array}{l}\text { Job Movers } \\
\text { (N: 3120) }\end{array}$ \\
\hline$U_{t}-U_{t-1}$ & $\begin{array}{l}-1.22 * \\
(0.26)\end{array}$ & $\begin{array}{l}-2.01 * \\
(0.40)\end{array}$ \\
\hline $\mathbf{U}_{\mathbf{t}}$ & $\begin{array}{l}-1.13 * \\
(0.28)\end{array}$ & $\begin{array}{l}-1.90 * \\
(0.47)\end{array}$ \\
\hline $\mathbf{U}_{\mathrm{t}-\mathbf{1}}$ & $\begin{array}{l}1.28 * \\
(0.26)\end{array}$ & $\begin{array}{l}2.04^{*} \\
(0.44)\end{array}$ \\
\hline FEMALES & $\begin{array}{c}\text { Job Stayers } \\
\text { (N: 11654) }\end{array}$ & $\begin{array}{l}\text { Job Movers } \\
\text { (N: 2433) }\end{array}$ \\
\hline$U_{t}-U_{t-1}$ & $\begin{array}{l}-1.30^{*} \\
(0.26)\end{array}$ & $\begin{array}{l}-1.73^{*} \\
(0.27)\end{array}$ \\
\hline $\mathbf{U}_{\mathbf{t}}$ & $\begin{array}{c}-1.24 * \\
(0.29)\end{array}$ & $\begin{array}{c}-1.67 * \\
(0.39)\end{array}$ \\
\hline $\mathbf{U}_{\mathrm{t}-1}$ & $\begin{array}{l}1.33^{*} \\
(0.27)\end{array}$ & $\begin{array}{c}1.75^{*} \\
(0.28)\end{array}$ \\
\hline
\end{tabular}

Notes: Standard errors in parentheses. ${ }^{*}$ denotes statistically significant at 0.05 level. 
Results shown refer to the second stage of the two-stage estimation procedure described in the text. There are 21 observations in this stage. In addition to the change in the unemployment rate, specifications include linear time trend and a cubic in labour market experience. First-stage regressions for job stayers additionally include a cubic in tenure in the current job.

The graphs in Figure 2 plot the estimated year dummies - from both the job stayers and job movers regressions - against an aggregate measure of the change in unemployment. The male and female graphs display remarkably similar procyclical wage movements. Clearly the three main events acting on the wage behaviour were (a) the recessionary period at the beginning of the Thatcher era in the early 1980s, (b) the 'Lawson boom' of the late 1980s, and (c) the early 1990's recession. At both unemployment peaks and troughs average rates of real wage increases among movers are significantly higher than their stayer equivale nts.

There are important caveats to be made when comparing the findings here and those of comparable United States work. The two main ones are that all job changes are recorded in the NESPD and that the sample is weighted strongly towards younger workers. So, while exercising due caution, it is worth reporting that the magnitude of the wage-unemployment responses of job stayers are very similar to those obtained in U.S. studies (e.g. Solon, Barsky and Parker, 1994). One interesting feature should be noted, however. Devereux (2001) finds in his U.S. study that limiting attention to job stayers who are not self-employed and who hold single jobs serves significantly to reduce estimated wage cyclicality. Estimates of the wage effects of the change in unemployment variable range from -1.16 with his full sample (i.e. aggregating over all job stayers and movers) to -0.54 on the more narrowly defined group. Job stayers in this study are virtually identical to this latter group but estimated cyclicality is twice this U.S. figure. Again, however, the relatively young ages of the samples here may account for at least part of this difference. 
Figure 2 Coefficients and year dummies and change in unemployment rate
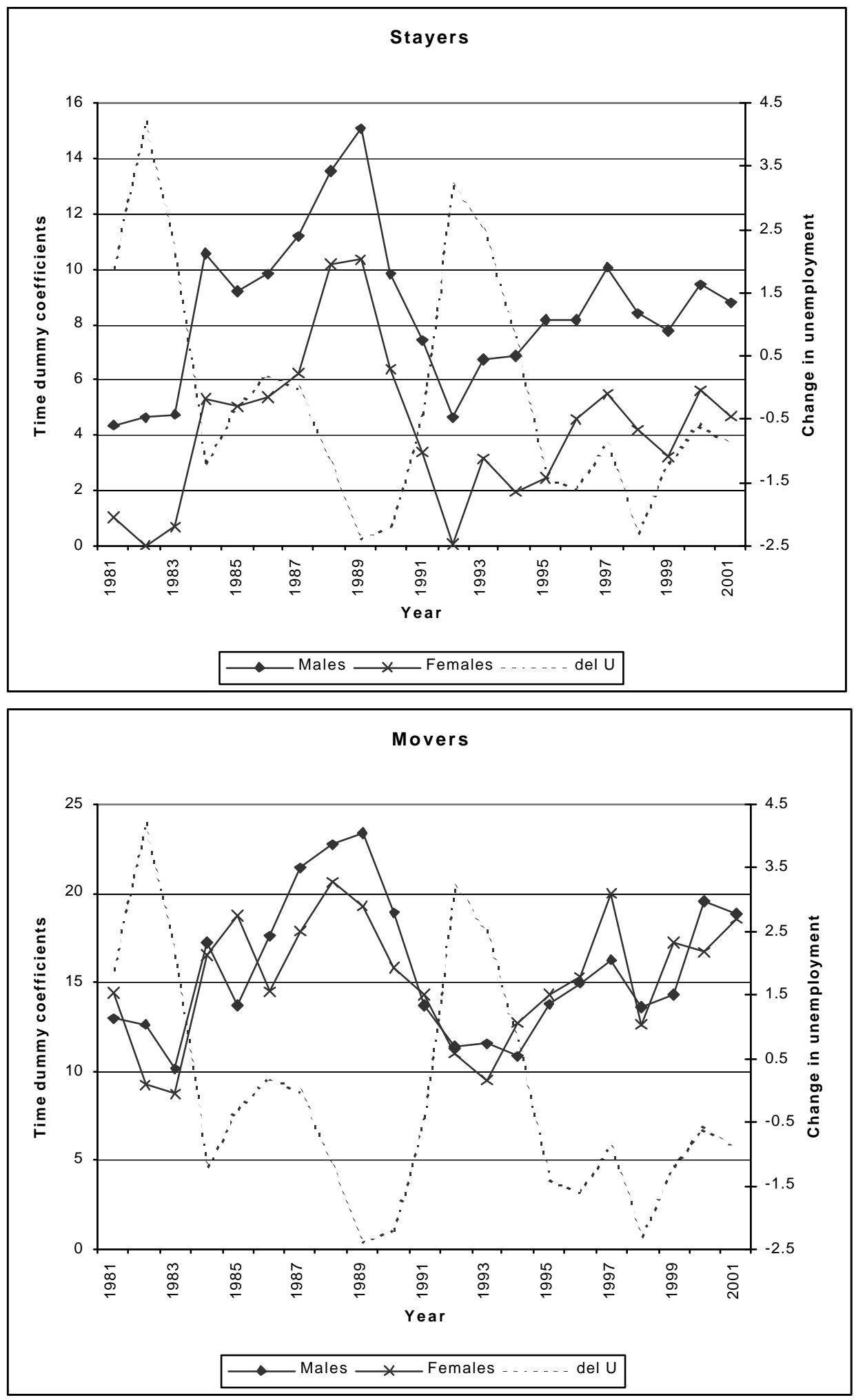
Devereux also delves deeper than most studies into investigating different types of compensation methods (e.g. hourly pay and salaries) and different types of wage (e.g. time rates and piece rates). He finds that wage procyclicality is be no means uniform across the sub-divisions with evidence of low cyclicality in some groups. Along these lines, and still concentrating on standard wages, I now break down the male and female samples into broad occupational categories. White collar workers are represented by (i) managers and professional workers, (ii) professional workers alone and (iii) non-manual occupations. Blue collar workers are represented by (1) manual occupations and (2) craft workers, plant and machine operatives and 'others'. The main findings are presented in Table 4. Perhaps somewhat surprisingly, given the preceding human capital arguments, wages of the white collar workers are no more procyclical than blue collar. ${ }^{8}$ Graphs like those shown in Figure 2 reveal highly procyclical and very close amplitudes and turning points between managerial and manual wokers. This runs counter to the U.S. evidence presented by Devereux.

Strong worker-job matches lead to long average job tenure and provide a basis for relatively high per-capita human capital and related organisational investments. If associated rent shares serve to dampen the degree of inter-temporal wage fluctuation then we might expect that the wage cyclicality of long-term job stayers is less than that of short-term job stayers. Let us define long-term stayers as remaining in a

\footnotetext{
${ }^{8}$ Of course, there are other labour market theories of wage procyclicality. Consider an efficiency wage story, for example. During cyclical downturns, increasing unemployment rates act as a worker discipline device. During expansionary periods, by contrast, unemployment has less bite and firms resort to higher wages in order to encourage work application and effort.
} 
single job for at least 5 years. ${ }^{9}$ How are strong job matches established? They may arise during initial stages of employment, through high expenditures by companies in search and hiring. In this event, we might expect lower wage cyclicality to be observed from the outset of job tenure. Alternatively, strong matches may result from a sorting and learning processes during early years on the job. Companies are more likely to invest in those workers who, through time, display the best work performance, aptitude and commitment. With this type of emphasis, it is more likely that lower wage cyclicality would manifest itself in later years of the tenure.

\section{Table 4 Effect of a change in the rate of unemployment on log of real hourly standard wages by main occupation groupings (job stayers) \\ (NESPD 1980 - 2001)}

\begin{tabular}{l|c|}
\hline Occupation group & Estimated coefficients on $\mathbf{U}_{\mathbf{t}}-\mathbf{U}_{\mathbf{t}-\mathbf{1}}$ \\
\hline $\begin{array}{l}\text { Managerial, professional and associate } \\
\text { professional/technical workers (N: 4339) }\end{array}$ & $-1.32^{*}$ \\
& $(0.31)$ \\
\hline $\begin{array}{l}\text { Professional and associate professional/ } \\
\text { technical workers (N: 2227) }\end{array}$ & $-1.50^{*}$ \\
& $(0.36)$ \\
\hline Non-manual occupations (N: 10624) & $-1.21^{*}$ \\
& $(0.27)$ \\
\hline Manual occupations (N: 5255) & $-1.19^{*}$ \\
& $(0.27)$ \\
\hline Craft workers, plant and machine operatives & $-1.32^{*}$ \\
and 'others' (N: 3842) & $(0.24)$ \\
\hline
\end{tabular}

\footnotetext{
${ }^{9}$ This is, of course, a somewhat arbitrary definition. In the related empirical work, defining long job stays as at least 6 or at least 7 years makes little difference to the estimates presented in Table 5.
} 
Job stayers are divided into those with job lengths equal to or greater than 5 years and those with completed stays of less than 5 years. Further, job stay periods of the former group are split into (a) those years equal to or in excess of and (b) those years up to the fifth year. Then the two step estimation procedure on all these categories was carried out. Results are shown in Table 5. There are two main sets of findings. First, male job stayers who leave their job before 5 years experience significantly more wage cyclicality than males remaining in a job for at least 5 years. The coefficient on the change in unemployment for male short stayers (less than 5 years) is -1.55 while it is -0.96 on average for long-stayers. The second set of findings concern a breakdown of the tenure spells of long-stayers. Over the initial four years of a long stay, the estimated male coefficient is well below comparable short stayers (1.1 compare with -1.55$)$. This supports the notion that strong initial job matching plays a role in reducing wage cyclicality early within long stay jobs. Wage cyclicality among long stayers during their fifth and later years are reduced even further, to -0.66 . This latter result supports the view that on- the-job human capital accumulation is also an important factor in suppressed wage cyclicality. The female results exhibit a very similar pattern. It is reasonable to infer that both initial job match and accumulated job experience serve to depress the resulting wage cyclicality of long-stayers.

Concentrating on job stayers, I now turn to the dichotomy between overtime and nonovertime workers. The estimates in Table 6 address the first of the three questions posed in Section 3. Is there a significant difference in the cyclicality of real standard pay between these two groups? Job spell lengths are divided into three categories: those consisting of individuals who (i) do not work overtime in all spells, (ii) work overtime in all spells, (iii) work overtime in at least one spell. The evidence supports the conclusion that there is slightly higher wage procyclicality among standard time 
workers. In general, however, it cannot be inferred overtime workers are more

protected against fluctuations in standard, or basic, pay.

Table 5 Effect of a change in rate of unemployment on log of average real hourly standard wages of job stayers with job lengths $\geq 5$ years and with job lengths $<5$ years (NESPD 1980 - 2001).

\begin{tabular}{|c|c|c|c|c|}
\hline MALES & \multicolumn{3}{|c|}{ Stayers with job lengths of at least 5 years } & \multirow{2}{*}{$\begin{array}{c}\text { Stayers with completed } \\
\text { job lengths of less than } 5 \\
\text { years } \\
(\mathrm{N}: 4949)\end{array}$} \\
\hline Variable & $\begin{array}{l}\text { All years } \\
(\mathrm{N}: 11991)\end{array}$ & $\begin{array}{c}\text { During early years } \\
\text { < 5 years } \\
(\mathrm{N}: 4721)\end{array}$ & $\begin{array}{c}\text { During later years } \\
\geq \mathbf{5} \text { years } \\
(\mathrm{N}: 7270)\end{array}$ & \\
\hline $\mathbf{U}_{t}-\mathbf{U}_{\mathrm{t}-1}$ & $\begin{array}{l}-0.96^{*} \\
(0.27)\end{array}$ & $\begin{array}{l}-1.10 * \\
(0.35)\end{array}$ & $\begin{array}{l}-0.66^{*} \\
(0.21)\end{array}$ & $\begin{array}{l}-1.55^{*} \\
(0.29)\end{array}$ \\
\hline $\mathbf{U}_{\mathbf{t}}$ & $\begin{array}{l}-0.93 * \\
(0.29)\end{array}$ & $\begin{array}{l}-0.91 * \\
(0.39)\end{array}$ & $\begin{array}{l}-0.61 * \\
(0.24)\end{array}$ & $\begin{array}{l}-1.17 * \\
(0.23)\end{array}$ \\
\hline $\mathbf{U}_{\mathrm{t}-1}$ & $\begin{array}{l}0.98 * \\
(0.27)\end{array}$ & $\begin{array}{l}1.23 * \\
(0.33)\end{array}$ & $\begin{array}{l}0.70 * \\
(0.22)\end{array}$ & $\begin{array}{l}1.72 * \\
(0.24)\end{array}$ \\
\hline FEMALES & \multicolumn{3}{|c|}{ Stayers with job lengths of at least 5 years } & $\begin{array}{c}\text { Stayers with job lengths } \\
\text { of less than } 5 \text { years }\end{array}$ \\
\hline Variable & $\begin{array}{l}\text { All years } \\
(\mathrm{N}: 7532)\end{array}$ & $\begin{array}{c}\text { During early years } \\
\text { < } 5 \text { years } \\
\text { (N: } 3478)\end{array}$ & $\begin{array}{c}\text { During later years } \\
\geq \mathbf{5} \text { years } \\
\text { (N: } 4054)\end{array}$ & $(\mathrm{N}: 4122)$ \\
\hline $\mathbf{U}_{t}-\mathbf{U}_{t-1}$ & $\begin{array}{l}-1.09 * \\
(0.21)\end{array}$ & $\begin{array}{l}-1.19 * \\
(0.20)\end{array}$ & $\begin{array}{l}-0.87 * \\
(0.29)\end{array}$ & $\begin{array}{l}-1.52 * \\
(0.36)\end{array}$ \\
\hline $\mathbf{U}_{\mathbf{t}}$ & $\begin{array}{l}-1.08^{*} \\
(0.24)\end{array}$ & $\begin{array}{l}-1.03 * \\
(0.18)\end{array}$ & $\begin{array}{l}-0.90 * \\
(0.32)\end{array}$ & $\begin{array}{l}-1.25^{*} \\
(0.37)\end{array}$ \\
\hline $\mathbf{U}_{\mathrm{t}-1}$ & $\begin{array}{l}1.09 * \\
(0.23)\end{array}$ & $\begin{array}{l}1.28 * \\
(0.22)\end{array}$ & $\begin{array}{l}0.84 * \\
(0.29)\end{array}$ & $\begin{array}{l}1.62 * \\
(0.34)\end{array}$ \\
\hline
\end{tabular}

Note: see Table 3.

Table 7 concentrates specifically on overtime pay. Column 1 reports the second stage regression outcomes where the average overtime premium in (5) replaces the standard wage. The results refer to individuals who worked overtime in every time spell 
during a job stay. The hypothesis that the average premium is cyclical is decisively rejected. This suggests that, predominantly, workers within this sample experienced a single premium rate throughout their job tenures. What about the cyclicality of real hourly wage earnings (i.e. including the effects of overtime)? The cyclicality of hourly earnings of overtime workers and standard wage of non-overtime wages can diverge even if (a) cyclicality with respect to standard rates is the same and (b) there is no cyclicality in the overtime premium. The reason is that procyclical total hours can change the proportion of premium pay to total pay of overtime worke rs. Column 2 of Table 7 shows the earnings results for overtime workers, using the broad definition of 'worked overtime in one or more job spells'. This reveals no increase in cyclicality relative to the standard wage result of these same workers (Column 3, Table 6) and the standard wage result of non-overtime workers (Column 1, Table 6).

Table 6 Effect of a change in rate of unemployment on log of average real hourly standard wages of job stayers. Non-overtime and overtime workers. (NESPD 1980 - 2001)

\begin{tabular}{|c||c|c|c|}
\hline Variable & $\begin{array}{c}\text { Non-overtime workers } \\
\text { (all spells) } \\
\text { (N: 4805) }\end{array}$ & $\begin{array}{c}\text { Overtime workers } \\
\text { (all spells) } \\
\text { (N: 1569) }\end{array}$ & $\begin{array}{c}\text { Overtime workers } \\
\text { (any spells) } \\
\text { (N: 12135) }\end{array}$ \\
\hline \multirow{2}{*}{$\mathbf{U}_{\mathbf{t}}-\mathbf{U}_{\mathbf{t}-\mathbf{1}}$} & $\begin{array}{c}-1.35^{*} \\
(0.33)\end{array}$ & -1.24 & $-1.19^{*}$ \\
& $(0.41)$ & $(0.25)$ \\
\hline \multirow{2}{*}{$\mathbf{U}_{\mathbf{t}}$} & $-1.19^{*}$ & -1.01 & $-1.12^{*}$ \\
& $(0.33)$ & $(0.42)$ & $(0.28)$ \\
$\mathbf{U}_{\mathbf{t}-\mathbf{1}}$ & $1.43^{*}$ & 1.39 & $-1.24^{*}$ \\
& $(0.33)$ & $(0.41)$ & $(0.26)$ \\
\hline
\end{tabular}

Notes: see Table 3. 
Table 7 Effect of a change in rate of unemployment on log of average overtime premium and real hourly standard earnings of overtime workers (job stayers) (NESPD 1980 - 2001)

\begin{tabular}{|c||c|c|}
\hline Variable & $\begin{array}{c}\text { Average Overtime premium } \\
\text { (N: 1569) }\end{array}$ & $\begin{array}{c}\text { Real hourly earnings of } \\
\text { overtime workers (any spells) } \\
\text { (N: 12135) }\end{array}$ \\
\hline \multirow{2}{*}{$\mathbf{U}_{\mathbf{t}}-\mathbf{U}_{\mathbf{t}-1}$} & 0.00 & $-1.20^{*}$ \\
& $(0.55)$ & $(0.25)$ \\
\hline \multirow{2}{*}{$\mathbf{U}_{\mathbf{t}}$} & 0.08 & $-1.13^{*}$ \\
& $(0.62)$ & $(0.28)$ \\
$\mathbf{U}_{\mathbf{t}-1}$ & 0.05 & $1.25^{*}$ \\
& $(0.81)$ & $(0.26)$ \\
\hline
\end{tabular}

Notes: see Table 3.

\section{Are British real wages more pro -cyclical than their United States equivalents?}

The wage estimates in Table 3 suggest that the degree British wage cyclicality among job stayers is about twice that of equivalent U.S. workers. There is an important caveat, however. Given the structure of the NESPD, obtaining a measure of labour market experience necessitates using a cohort of individuals - born in a specific time period and following their year-by-year progress through the panel survey. This restricts individual ages to between 16 (minimum school leaving age) and 43 years (maximum age in 2001). Therefore, the stronger wage cyclicality in this study may simply reflect wage changes within a relatively young cohort.

Before a firmer comparison can be made, we need to use all age groups from the NESPD. Concentrating on job stayers, the following strategy is adopted. ${ }^{10}$ First, I drop experience from the regressions thereby enabling me to utilise the complete 1980 - 
2001 male and female data. ${ }^{11}$ Second, I estimate regressions using individuals aged $\leq$ 43 years. These results are compared with their equivalents in Table 3. Suppose these are found to be similar to my original Table 3 estimates - i.e. the experience variable doesn't alter things very much. Then, third, I run the regressions for all ages and compare these with the $\leq 43$ year olds.

Results to this experiment are shown in Table 8. Estimated male wage cyclicality for the $\leq 43$ year olds is reduced somewhat compared to the equivalent Table 3 estimates (-1.08 compared with -1.22$)$ and marginally reduced for females (-1.22 compared with 1.30). But, for both genders, these estimates remain at almost double Devereux's (2001) comparable U.S. estimates. When all ages are included, the results in Table 8 are virtually the same as their $\leq 43$ year old equivalents. These results reinforce the earlier findings of greater wage cyclicality in Britain than in the United States, a country noted for its relatively flexible labour market.

\footnotetext{
${ }^{10}$ I am grateful to Paul Devereux for suggesting this to me.

${ }^{11}$ However, only completed job spells are used. Where an individual leaves the panel for one or more period and returns - either with or without a marker in dicating a new job - the incomplete job spells are not included.
} 
Table 8 Effect of a change in rate of unemployment on log of real standard hourly wage rates: job stayers aged $\leq 43$ years and all job stayers (NESPD 1980 - 2001)

\begin{tabular}{|c|c|c|}
\hline MALES & $\begin{array}{c}\text { Job Stayers aged } \leq 43 \text { years } \\
(\mathrm{N}: 41368)\end{array}$ & $\begin{array}{l}\text { All job stayers } \\
(\mathrm{N}: \mathbf{5 6 0 6 3 )}\end{array}$ \\
\hline $\mathbf{U}_{t}-\mathbf{U}_{\mathrm{t}-1}$ & $\begin{array}{c}-1.08 * \\
(0.22)\end{array}$ & $\begin{array}{l}-1.11 * \\
(0.25)\end{array}$ \\
\hline $\mathbf{U}_{\mathbf{t}}$ & $\begin{array}{c}-1.10^{*} \\
(0.24)\end{array}$ & $\begin{array}{l}-0.96 * \\
(0.27)\end{array}$ \\
\hline $\mathbf{U}_{\mathrm{t}-\mathbf{1}}$ & $\begin{array}{c}1.07 * \\
(0.24)\end{array}$ & $\begin{array}{l}1.16^{*} \\
(0.26)\end{array}$ \\
\hline FEMALES & $\begin{array}{c}\text { Job Stayers aged } \leq 43 \text { years } \\
(\mathrm{N}: \mathbf{4 1 8 9 4})\end{array}$ & $\begin{array}{l}\text { All job stayers } \\
(\mathrm{N}: \mathbf{5 7 1 0 6})\end{array}$ \\
\hline $\mathbf{U}_{t}-\mathbf{U}_{\mathrm{t}-\mathbf{1}}$ & $\begin{array}{c}-1.22 * \\
(0.25)\end{array}$ & $\begin{array}{l}-1.21 * \\
(0.26)\end{array}$ \\
\hline $\mathbf{U}_{\mathbf{t}}$ & $\begin{array}{c}-1.23 * \\
(0.25)\end{array}$ & $\begin{array}{l}-1.16^{*} \\
(0.28)\end{array}$ \\
\hline $\mathbf{U}_{\mathrm{t}-\mathbf{1}}$ & $\begin{array}{c}1.22 * \\
(0.25)\end{array}$ & $\begin{array}{l}1.23 * \\
(0.27)\end{array}$ \\
\hline
\end{tabular}

Notes: These regressions do not include an experience variable, otherwise the notes to Table 3 pertain. 


\section{Conclusions}

In recent Europe-wide debates, the claim is often made that Britain enjoys a relatively flexible labour market. A major aspect of such an assessment relates to pay. Flexible wages offer companies a competitive edge in their needto adjust output prices and factor costs to changing economic conditions. In terms of wage responsiveness to fluctuations in economic activity, this paper supports the notion that British real wages are strongly procyclical. This is true for both job stayers and job movers. Cyclicality is especially strong among the latter group. Moreover, males and females display very similar wage reactions. For job stayers, British wage cyclicality is far more pronounced than in comparable U.S. data.

The more detailed findings do not detract greatly from the central message of strong wage procyclicality. Professional and managerial workers experience very similar wage responsiveness to blue collar workers. Working overtime seems to have a relatively small bearing on the degree of wage cyclicality. However, wage cyclicality is reduced somewhat among those job stayers who remain in a job for longer than five years and, especially, in their later years of job tenure. 


\section{References}

Aoki, M. 1984. The co-operative game theory of the firm. Oxford: Oxford University Press.

Bartel, A and G Borjas. 1982. Wage growth and job turnover: an empirical analysis. In S Rosen (ed.), Studies in labor markets. Chicago: University of Chicago Press for NBER.

Devereux, P J. 2001. The cyclicality of real wages within employer-employee matches. Industrial and Labor Relations Review 54: 835-850.

Bils, M. 1985. Real wages over the business cycle: evidence from panel data. Journal of Political Economy 93: 666-689.

Card, D. 1995. The wage curve: a review. Journal of Economic Literature 33: 785799.

Hart, R A an R J Ruffell. 1993. The cost of overtime hours in British production industries. Economica 60: 183-201.

Hashimoto, M. 1979. Bonus payments, on-the-job training, and lifetime employment in Japan. Journal of Political economy 87: 1086-104.

Incomes Data Services. 1997. Overtime. Study 617. London: Income Data Services Ltd.

Mincer J. 1986. Wage changes and job changes. Research in labor economics 8. Greenwich, CT: JAI Press: 171-191.

Mincer, J and B Jovanovic. 1981. Labor mobility and wages. In S Rosen (ed.), Studies in labor markets. Chicago: University of Chicago Press for NBER.

Moulton, B R. 1986. Random group effects and the precision of regression estimates. Journal of Econometrics 32: 385-397.

Rosen, S. 1985. Implicit contracts: a survey. Journal of Economic Literature 23, 11441175.

Rosenbaum, J E. 1979. Tournament mobility: career patterns in a corporation, Administrative Science Quarterly 24: 220-41.

Rosenbaum, J E. 1984. Career mobility in a corporate hierarchy. New York: Academic Press.

Topel, R H and M P Ward. 1992. Job mobility and the careers of young men. Quarterly Journal of Economics 107: 439-479.

Santämaki, T. 1983. The overtime pay premium, hours of work, and employment. Helsinki School of Economics, Working Paper F-75. 
Solon, G R, Barsky, and J A Parker. 1994. Measuring the cyclicality of real wages: how important is composition bias? Quarterly Journal of Economics 109:1 -26. 


\section{IZA Discussion Papers}

\begin{tabular}{|c|c|c|c|c|}
\hline No. & Author(s) & Title & Area & Date \\
\hline 867 & $\begin{array}{l}\text { T. J. Dohmen } \\
\text { B. Kriechel } \\
\text { G. A. Pfann }\end{array}$ & $\begin{array}{l}\text { Monkey Bars and Ladders: The Importance of } \\
\text { Lateral and Vertical Job Mobility in Internal } \\
\text { Labor Market Careers }\end{array}$ & 1 & $08 / 03$ \\
\hline 868 & $\begin{array}{l}\text { P. Brañas Garza } \\
\text { S. Neuman }\end{array}$ & $\begin{array}{l}\text { Analyzing Religiosity Within an Economic } \\
\text { Framework: The Case of Spanish Catholics }\end{array}$ & 5 & $08 / 03$ \\
\hline 869 & $\begin{array}{l}\text { A. B. Krueger } \\
\text { A. Mas }\end{array}$ & $\begin{array}{l}\text { Strikes, Scabs and Tread Separations: Labor } \\
\text { Strife and the Production of Defective } \\
\text { Bridgestone/Firestone Tires }\end{array}$ & 3 & $09 / 03$ \\
\hline 870 & $\begin{array}{l}\text { S. Klasen } \\
\text { A. Launov }\end{array}$ & $\begin{array}{l}\text { Analysis of the Determinants of Fertility Decline } \\
\text { in the Czech Republic }\end{array}$ & 4 & $09 / 03$ \\
\hline 871 & $\begin{array}{l}\text { Y. L'Horty } \\
\text { C. Rault }\end{array}$ & $\begin{array}{l}\text { The Impact of Growth, Labour Cost and Working } \\
\text { Time on Employment: Lessons from the French } \\
\text { Experience }\end{array}$ & 5 & $09 / 03$ \\
\hline 872 & $\begin{array}{l}\text { J. R. Munch } \\
\text { M. Rosholm } \\
\text { M. Svarer }\end{array}$ & Are Home Owners Really More Unemployed? & 1 & $09 / 03$ \\
\hline 873 & $\begin{array}{l}\text { M. Falk } \\
\text { B. M. Koebel }\end{array}$ & $\begin{array}{l}\text { The Impact of Office Machinery and Computer } \\
\text { Capital on the Demand for Heterogeneous } \\
\text { Labour }\end{array}$ & 5 & $09 / 03$ \\
\hline 874 & J.-S. Pischke & $\begin{array}{l}\text { The Impact of Length of the School Year on } \\
\text { Student Performance and Earnings: Evidence } \\
\text { from the German Short School Years }\end{array}$ & 6 & $09 / 03$ \\
\hline 875 & C. Grund & $\begin{array}{l}\text { Severance Payments for Dismissed Employees } \\
\text { in Germany }\end{array}$ & 3 & $09 / 03$ \\
\hline 876 & $\begin{array}{l}\text { M. Karanassou } \\
\text { H. Sala } \\
\text { D. J. Snower }\end{array}$ & $\begin{array}{l}\text { The European Phillips Curve: Does the NAIRU } \\
\text { Exist? }\end{array}$ & 3 & $09 / 03$ \\
\hline 877 & M.-S. Yun & Decomposing Differences in the First Moment & 3 & $09 / 03$ \\
\hline 878 & $\begin{array}{l}\text { J. T. Addison } \\
\text { C. Schnabel } \\
\text { J. Wagner }\end{array}$ & $\begin{array}{l}\text { The Course of Research into the Economic } \\
\text { Consequences of German Works Councils }\end{array}$ & 3 & $09 / 03$ \\
\hline 879 & $\begin{array}{l}\text { A. Constant } \\
\text { Y. Shachmurove }\end{array}$ & $\begin{array}{l}\text { Entrepreneurial Ventures and Wage Differentials } \\
\text { Between Germans and Immigrants }\end{array}$ & 1 & $09 / 03$ \\
\hline 880 & $\begin{array}{l}\text { W. Koeniger } \\
\text { A. Vindigni }\end{array}$ & $\begin{array}{l}\text { Employment Protection and Product Market } \\
\text { Regulation }\end{array}$ & 2 & $10 / 03$ \\
\hline 881 & R. A. Hart & $\begin{array}{l}\text { Worker-Job Matches, Job Mobility, and Real } \\
\text { Wage Cyclicality }\end{array}$ & 1 & $10 / 03$ \\
\hline
\end{tabular}

An updated list of IZA Discussion Papers is available on the center's homepage www.iza.org. 